\title{
HUBUNGAN PENGETAHUAN DAN SIKAP DENGAN POLA MAKAN SEBAGAI FAKTOR RESIKO DIABETES MELITUS
}

\section{ASSOCIATION BETWEEN KNOWLEDGE AND ATTITUDE WITH EATING PATTERN AS RISK FACTORS OF DIABETES MELITUS}

\author{
Alfeus Manuntung \\ Jurusan Keperawatan Poltekkes Kemenkes Palangka Raya \\ E-mail : alfeusmanuntung@gmail.com
}

\begin{abstract}
ABSTRAK
Diabetes Melitus merupakan kumpulan gejala yang timbul pada seseorang akibat peningkatan kadar gula darah yang disebabkan oleh kekurangan insulin. Pola makan yang kurang baik merupakan salah satu pemicu utama tingginya prevalensi penyakit Diabetes Melitus. Tujuan dari penelitian ini adalah untuk mengetahui hubungan tingkat pengetahuan dan sikap dengan pola makan terkait faktor risiko Diabetes Melitus pada mahasiswa Jurusan Keperawatan di Poltekkes Kemenkes Palangka Raya. Penelitian ini menggunakan metode penelitian deskriptif dengan pendekatan cross sectional, digunakan untuk mengetahui hubungan yang signifikan antara dua variabel. Sampel pada penelitian ini yaitu 62 responden. Analisa data menggunakan uji Chi Square (crosstabs). Hasil penelitian ini menunjukkan terdapat hubungan yang signifikan antara sikap dengan perilaku pola makan dengan nilai $\rho$-value $0,03(\alpha \leq 0,05)$ dan tidak terdapat hubungan antara pengetahuan dengan pola makan responden dengan nilai $\rho$-value 0,663 atau $(\alpha>0,05)$. Dengan demikian pengetahuan yang baik tidak menjamin seseorang tersebut memiliki pola makan yang sesuai. Peneliti lain dapat mengembangkan penelitian ini, yaitu dengan menambahkan variabel lain baik faktor intrinsik maupun ekstrinsik, memperluas subyek penelitian serta melakukan penelitian lebih lanjut untuk mengetahui pola makan dengan mengukur food intake atau asupan gizinya perhari.
\end{abstract}

Kata Kunci: Pengetahuan, Sikap, Pola makan

\begin{abstract}
Diabetes mellitus is a collection of symptoms that arise in a person due to increased blood sugar levels caused by insulin deficiency. Poor diet is one of the main triggers of the high prevalence of Diabetes Mellitus. The purpose of this study was to determine the relationship between the level of knowledge and attitudes with eating patterns related to diabetes mellitus risk factors in Nursing Department students at the Polytechnic of the Ministry of Health Palangka Raya. This research uses descriptive research method with cross sectional approach, used to find out the significant relationship between two variables. The sample in this study was 62 respondents. Data analysis uses Chi Square test (crosstabs). The results of this study indicate that there is a significant relationship between attitude and eating behavior with a $p$ value of 0.03 or $<0.05$ and there is no relationship between knowledge and the respondent's diet with a $p$-value of 0.663 or $p>0.05$. Thus good knowledge does not guarantee a person has an appropriate diet. Other researchers can develop this research, namely by adding other variables both intrinsic and extrinsic factors and expanding research subjects, as well as conducting further research to determine dietary patterns by measuring food intake or nutritional intake.
\end{abstract}

Keywords : Attitude, Knowledge, Diet 


\section{PENDAHULUAN}

Diabetes Melitus merupakan salah satu penyakit yang tidak menular. Badan Kesehatan Dunia (WHO) memprediksi bahwa adanya peningkatan jumlah penyandang Diabetes Melitus yang menjadi salah satu ancaman kesehatan global. Hasil prediksi WHO pada Tahun 2015 terdapat 415 juta orang dewasa usia 20-79 tahun dengan Diabetes. Kenaikan 4 kali lipat pada Tahun 2040 yang diperkirakan jumlah penyandang Diabetes Melitus sebanyak 642 juta. $^{1}$

Diabetes Melitus atau penyakit kencing manis merupakan suatu penyakit menahun yang ditandai dengan kadar glukosa darah (gula darah) melebihi nilai normal yaitu kadar gula darah sewaktu sama atau lebih dari $200 \mathrm{mg} / \mathrm{dl}$, dan kadar gula darah puasa sama atau lebih dari $126 \mathrm{mg} / \mathrm{dl}^{2}$

Hasil Riskesdas Tahun 2013 diperoleh d proporsi Diabetes Melitus pada usia 15 tahun ke atas. Penyandang DM di Kalimantan Tengah dengan proporsi penduduk yang pernah didiagnosis menderita kencing manis oleh dokter berjumlah 19.299 orang atau $1,2 \%$. Untuk yang belum pernah didiagnosis menderita kencing manis oleh dokter tetapi dalam 1 bulan terakhir mengalami gejala sering lapar, sering haus, sering buang air kecil dengan jumlah banyak dan berat badan turun berjumlah 6.433 orang atau $0,4 \%{ }^{3}$

Gaya hidup merupakan kebiasaan-kebiasaan yang dilakukan dan dapat berpengaruh terhadap kesehatan seseorang khususnya peningkatan kadar gula darah. Pada penyandang DM maupun pada orang yang sehat pentingnya pengaturan makanan yang terdiri atas komposisi makanan, kebutuhan kalori jenis dan pilihan makanan, serta jadwal makan. Pola makan tinggi lemak, tinggi kalori dan rendah serat yang dikenal dengan fast food dapat sebagai pemicu timbulnya penyakit Diabetes Melitus atau penyakit degeneratif lainnya. ${ }^{4}$

Banyak faktor yang merupakan faktor risiko Diabetes Melitus. Faktor tersebut dikelompokkan menjadi tiga kelompok, yaitu sosiodemografi, faktor perilaku dan gaya hidup serta keadaan klinis atau status mental. Sosiodemografi terdiri dari umur dan jenis kelamin. Faktor perilaku dan gaya hidup terdiri dari kebiasaan merokok, konsumsi alkohol, pola makan, aktivitas fisik, konsumsi serat, pola tidur, konsumsi soft drink dan fast food sedangkan keadaan klinis atau status mental seperti obesitas, genetika dan stres. Berdasarkan faktor risiko Diabetes Melitus tersebut hal yang paling mendasar dan tidak dapat dihindari adalah makan. Hal ini dikarenakan makan merupakan salah satu aktivitas pasti dalam keseharian kita. $^{5}$

Pola makan merupakan suatu cara atau usaha dalam pengaturan jumlah dan jenis makanan dengan maksud tertentu seperti mempertahankan kesehatan, status nutrisi, mencegah atau membantu kesembuhan penyakit. Pola makan sehari-hari merupakan pola makan seseorang yang berhubungan dengan kebiasaan makan setiap harinya. Pola makan sehat untuk Diabetesi adalah $25-30 \%$ lemak, $50-55 \%$ karbohidrat, dan $20 \%$ protein.

Gaya hidup di perkotaan dengan pola makan yang tinggi lemak, garam, dan gula mengakibatkan masyarakat cenderung mengkonsumsi makanan secara berlebihan. Selain itu pola makanan yang serba instan saat ini memang sangat digemari oleh sebagian masyarakat, tetapi dapat mengakibatkan peningkatan kadar glukosa darah. Penyakit menahun yang disebabkan oleh penyakit degeneratif seperti Diabetes Melitus meningkat sangat tajam. Perubahan pola penyakit ini diduga berhubungan dengan cara hidup yang berubah. $^{6}$

Pola makan di kota-kota telah bergeser dari pola makan yang tradisional yang banyak mengandung karbohidrat dan serat dari sayuran berubah menjadi pola makan yang kebarat-baratan dan sedikit serat. Komposisi makanan yang tinggi lemak, garam, dan sedikit serat pada makanan siap saji yang pada akhir-akhir ini sangat digemari di kalangan masyarakat Indonesia. Penyakit Diabetes Melitus merupakan penyakit degeneratif yang sangat terkait pola makan. Saat ini, banyak remaja yang 
menyukai makanan cepat saji atau fast food. Remaja yang memiliki aktivitas sosial yang tinggi, cenderung memperlihatkan interaksi dengan teman sebaya. Di kota besar, banyak dijumpai sekelompok remaja yang makan bersama di tempat makan yang menyediakan makanan cepat saji atau fast food. Makanan cepat saji tersebut berasal dari negara barat yang umumnya memiliki kandungan lemak dan kalori yang tinggi. Apabila dikonsumsi dalam jumlah banyak setiap hari, maka dapat menyebabkan obesitas. Obesitas atau kegemukan ini dapat menyebabkan timbulnya masalah gizi lainnya. Berdasarkan hasil pengamatan sebagian besar mahasiswa mengalami obesitas dengan resiko diabetes melitus.

Berdasarkan uraian latar belakang atau permasalahan yang telah dijelaskan, maka peneliti tertarik untuk melakukan penelitian mengenai hubungan pengetahuan dan sikap dengan pola makan sebagai faktor resiko diabetes melitus pada mahasiswa jurusan keperawatan di Poltekkes Kemenkes Palangka Raya.

\section{METODE PENELITIAN}

Penelitian ini menggunakan metode deskriptif dengan pendekatan Cross Sectional. Pengambilan sampel pada penelitian ini menggunakan Purposive Sampling yaitu penetapan sampel dengan cara memilih sampel diantara populasi sesuai dengan yang dikehendaki peneliti. ${ }^{7}$

Populasi penelitian ini adalah mahasiswa reguler program studi D.III Keperawatan semester IV berjumlah 30 mahasiswa dan mahasiswa reguler program studi D.IV Keperawatan semester VI berjumlah 32 mahasiswa sehingga jumlah sampel pada penelitian ini yaitu 62 responden. Jumlah sampel didapatkan dari perhitungan dengan menggunakan rumus Slovin. Kriteria insklusi pada penelitian ini yaitu mahasiswa keperawatan yang aktif kuliah, bersedia menjadi responden penelitian dan mahasiswa berada ditempat pada saat penelitian dilaksanakan. Sementara untuk kriteria eksklusi yaitu mahasiswa sedang sakit saat penelitian dilaksanakan. Penelitian ini dilaksanakan pada bulan Maret-Mei 2019 di kampus jurusan keperawatan Poltekkes Kemenkes Palangka Raya.

Peneliti menggunakan teknik pengumpulan data primer, yaitu data yang dikumpulkan dan diolah sendiri oleh peneliti langsung dari subyek atau obyek penelitian. Data primer dengan menggunakan kuesioner. Peneliti memberikan Inform Consent kepada responden, menjelaskan semua prosedur penelitian ini. Analisis data yang digunakan yaitu uji Chi Square dengan syarat sampel dipilih secara acak, semua pengamatan dilakukan dengan independen, setiap sel paling sedikit berisi frekuensi harapan sebesar 1 (satu). Sel-sel dan frekuensi harapan kurang dari 5 tidak melebihi $20 \%$ dari total sel dan besar sampel sebaiknya $>40$.

\section{HASIL}

Tabel 1. Hubungan Tingkat Pengetahuan dan Sikap dengan Pola Makan

\begin{tabular}{|c|c|c|c|c|c|}
\hline \multirow{4}{*}{ Variabel } & \multicolumn{4}{|c|}{ Pola Makan } & \multirow{4}{*}{$p$} \\
\hline & \multirow{2}{*}{\multicolumn{2}{|c|}{$\begin{array}{l}\text { Sesuai } \\
\text { PUGS }\end{array}$}} & \multirow{2}{*}{\multicolumn{2}{|c|}{$\begin{array}{l}\text { Tidak } \\
\text { sesuai } \\
\text { PUGS }\end{array}$}} & \\
\hline & & & & & \\
\hline & $n$ & $\%$ & $\mathrm{n}$ & $\%$ & \\
\hline \multicolumn{6}{|l|}{ Pengetahuan } \\
\hline Baik & 19 & 82,7 & 29 & 74,3 & \multirow{3}{*}{0,63} \\
\hline Kurang Baik & 4 & 17,3 & 10 & 25,7 & \\
\hline Total & 23 & 100 & 39 & 100 & \\
\hline \multicolumn{6}{|l|}{ Sikap } \\
\hline Positif & 15 & 65,2 & 13 & 33,3 & \multirow{3}{*}{0,03} \\
\hline Negatif & 8 & 34,8 & 26 & 66,7 & \\
\hline Total & 23 & 100 & 39 & 100 & \\
\hline
\end{tabular}

Berdasarkan Tabel 1 diketahui terdapat 19 responden berpengetahuan baik dengan pola makan sesuai PUGS (82,7\%). Ada 29 responden berpengetahuan baik dengan pola makan tidak sesuai PGUS $(74,3 \%)$ dan 4 responden berpengetahuan kurang baik dengan pola makan sesuai PGUS $(17,3 \%)$ dan 10 responden berpengetahuan kurang baik dengan pola makan tidak sesuai PUGS (25,7\%). Hasil uji hubungan pengetahuan dengan pola makan didapatkan nilai $\rho$-value 0,633 . Hal ini menunjukkan tingkat kemaknaan $(\alpha>0,05)$ yang berarti tidak terdapat hubungan antara tingkat pengetahuan dengan pola makan. 
Berdasarkan Tabel 1 diketahui juga terdapat 15 responden bersikap positif dengan pola makan sesuai PUGS (65,2\%). Ada 13 responden bersikap positif dengan pola makan tidak sesuai PGUS (33,3\%). 8 responden bersikap negatif dengan pola makan sesuai PGUS (34,8\%) dan 26 responden bersikap negatif dengan pola makan tidak sesuai PUGS (66,7\%). Hasil uji hubungan sikap dengan pola makan didapatkan nilai $\rho$-value 0,030 . Hal ini menunjukkan tingkat kemaknaan $(\alpha<0,05)$ yang berarti terdapat hubungan yang signifikan antara sikap dengan pola makan.

\section{PEMBAHASAN}

Pola makan merupakan suatu cara atau usaha dalam pengaturan jumlah dan jenis makanan dengan maksud tertentu seperti mempertahankan kesehatan, status nutrisi, mencegah atau membantu kesembuhan penyakit. Pola makan sehari-hari merupakan pola makan seseorang yang berhubungan dengan kebiasaan makan setiap harinya. ${ }^{8}$

Hasil uji kolerasi chi-square diperoleh nilai $\rho$ sebesar $0,663(\alpha>0,05)$. Hasil penelitian ini menunjukkan tidak ada hubungan yang bermakna antara pengetahuan dengan pola makan. Hasil penelitian ini sejalan dengan penelitian Syifa Puji pada Tahun 2018 yang mengatakan tidak terdapat hubungan antara pengetahuan dengan pola makan. Hal ini dikarenakan pengetahuan yang mereka miliki tidak diaplikasikan di kehidupan mereka sehari-hari. Pengetahuan merupakan hasil tahu dan ini terjadi setelah orang melakukan penginderaan terhadap suatu objek tertentu. Pengetahuan atau kognitif merupakan domain yang sangat penting untuk terbentuknya tindakan seseorang. ${ }^{9}$

Hasil penelitian menunjukkan sebagian besar mahasiswa mengetahui pola makan mereka yang diterapkan selama ini kurang tepat. Mereka tahu jika terus menerus mengkonsumsi makanan siap saji dapat menyebabkan risiko terkena Diabetes Melitus. Hasil penelitian ini sejalan dengan penelitian Syifa Puji pada Tahun 2018 yang mengatakan terdapat hubungan antara sikap dengan pola makan. Hal itu diperlukan adanya suatu keinginan, niat atau sikap yang positif seseorang untuk dapat mencapai pola makan yang baik.

Sikap adalah merupakan reaksi atau respon seseorang yang masih tertutup terhadap suatu stimulus atau objek. Pendapat lainnya sikap adalah kecenderungan bertindak dari individu, berupa respon tertutup terhadap stimulus ataupun objek tertentu. Sikap merupakan reaksi atau respon yang masih tertutup dari seseorang terhadap suatu stimulus atau objek. ${ }^{10}$ Sikap belum merupakan suatu tindakan atau aktivitas, akan tetapi merupakan predisposisi tindakan suatu perilaku. Sikap merupakan kesiapan untuk bereaksi terhadap objek di lingkungan tertentu sebgai suatu penghayatan terhadap objek. ${ }^{11}$

Faktor lainnya yang mempengaruhi sikap seseorang adalah adanya stimulus dari faktor internal (fisiologis dan psikologis) maupun faktor ekternal seperti pengaruh orang lain, kebudayaan, dan lingkungan sekitar. Sikap dapat berubah melalui tiga proses yaitu kesediaan, identifikasi dan internasilasi. Kesediaan terjadi ketika individu bersedia menerima pengaruh dari orang lain atau kelompok lain dikarenakan individu berharap untuk memperoleh reaksi atau tanggapan positif dari pihak lain tersebut. Identifikasi terjadi saat individu meniru perilaku atau sikap seseorang sekelompok lain dikarenakan sikap tersebut sesuai dengan apa yang dianggap individu sebagai bentuk hubungan yang menyenangkan antara individu dengan pihak lain. Internalisasi terjadi saat individu menerima pengaruh dan bersedia bersikap menurut pengaruh itu dikarenakan sikap tersebut sesuai dengan apa yang dipercayai individu. ${ }^{12}$

\section{SIMPULAN DAN SARAN}

Seseorang yang memiliki pengetahuan tentang pola makan yang baik memungkinkan untuk memiliki pola makan yang tidak sesuai dengan pedoman umum gizi seimbang. Karena dengan pengetahuan yang baik tidak menjamin seseorang tersebut memiliki pola makan yang sesuai. Seseorang yang bersikap negatif berpengaruh terhadap perilaku pola makan nya menjadi tidak 
sesuai sehingga kebutuhan gizinya tidak terpenuhi atau bahkan berlebihan. ${ }^{13}$ Saran dari penelitian ini untuk remaja atu mahasiswa untuk mencegah Diabetes melitus yaitu mengurangi makanan siap saji, mengatur porsi makan, hindari makanan yang berlemak dan manis, rajin olahraga.

\section{UCAPAN TERIMA KASIH}

Peneliti berterima kasih kepada mahasiswa Program Studi D.III dan D.IV jurusan Keperawatan yang bersedia menjadi responden pada penelitian ini.

\section{DAFTAR PUSTAKA}

1. World Health Organization.Diabetes Fact an Figures.[Internet].2016.[dikunjungi 16 Desember 2018] tersedia dari htpp://www.who.int/

2. Holistic Health Solution.Diabetes di Usia Muda.Jakarta:Gramedia Widiasarana Indonesia;2011.

3. Riset Kesehatan Dasar Badan Penelitian dan Pengembangan Kesehatan Kementerian Kesehatan RI.Jakarta: Riskesda 2013.

4. Astawan, Made. Panduan Lengkap Menjaga Kesehatan. Jakarta :Dian Rakyat:2018.

5. Misnadiarly.Diabetes Melitus: Gangren, Ulcer, Infeksi. Mengenal Gejala, Menanggulangi, dan Mencegah

Komplikasi.Jakarta:Pustaka Populer Obor;2016.
6. Depkes, RI. 2008. Pedoman Umum Gizi Seimbang. Jakarta: Ditjen Pembinaan Kesehatan Masyarakat Direktorat Bina Gizi Masyarakat.

7. Notoatmojo, S.Metodologi Penelitian Kesehatan.Jakarta:Rineka Cipta;2012.

8. Sebayang.2012.Gambaran Pola Konsumsi Makanan Mahasiswa di Universitas Indonesia. Diunduh dari http://lib.ui.ac.id/file?file=digital/20312 384-S43474-Gambaran\%20pola.pdf. Diakses pada tanggal 8 Januari 2019.

9. Puji, Syifa. Faktor-Faktor yang Berhubungan dengan Pola Makan Mahasiswa Kesehatan Masyarakat Fakultas Kedokteran dan IImu Kesehatan Universitas Islam Negeri Syarif Hidayatullah Jakarta tahun 2018.[Skripsi].

10. Soegondo,S.Diagnosis dan klasifikasi Diabetes Melitus terkini. Dalam Penatalaksanaan Diabetes Melitus Terpadu.Jakarta: Balai Penerbit FKUI;2012.

11. Tandra,Hans.Segala Sesuatu yang Harus Anda Ketahui tentang Diabetes. Jakarta:Gramedia Pustaka Utama;2017.

12. Umar, F. A. , Bodhi, W., Kepel, B. J. 2013. Gambaran Gula Darah Pada Remaja Obes Di Minahasa, Jurnal EBiomedik, Manado, 1 : 266.

13. Manuntung, Alfeus.Analisis Keyakinan Diri Pasien Diabetes Melitus Dalam Pengelolaan Diabetes Melitus.Jurnal Kesehatan Manarang Vol.3 No.1 Juli;2017. 